\title{
Morphosyntax of verb movement and Afrikaans verbal constructions ${ }^{1}$
}

\author{
Eric J. C. Vriends \\ University of Stellenbosch
}

\section{Introduction}

In his Morphosyntax of verb movement: a minimalist approach to the syntax of Dutch (1997) Zwart argues for an alternative analysis to the traditional analysis ${ }^{2}$ of the word order variation that exists in West Germanic subject initial main clauses and embedded clauses. This alternative analysis is a heavily revised version of the one Zwart presented in his 1993 dissertation. The revised version focuses on a smaller section of Dutch syntax than the preceding work and revolves crucially around a proposal of feature movement and the interaction between syntax and morphology. It also deviates from the traditional analysis in the assumption that the underlying word order for Dutch is SVO and that all functional projections are head initial. Zwart (1997) furthermore claims that the analysis presented for Dutch can be carried over to the other West Germanic languages. At least one of these languages, Afrikaans, is not discussed by Zwart and my main interest in this article is to see whether Zwart's proposed analysis holds when applied to this language.

\section{A minimalist analysis of verb movement}

We will now familiarise ourselves with the relevant parts of Zwart's (1997) analysis of verb movement asymmetry in Germanic languages. First we will look at the assumptions $\mathrm{Zwart}$ makes for the underlying word order and the position of the heads in Dutch. Then we will look at the phenomenon of double (complementiser) agreement, which provides the empirical argument for Zwart to assume the existence of AgrS-to-C movement. After that we will look at Zwart's proposals about feature movement and postlexicalism, which form the basis of his

\footnotetext{
1 This article is an unrevised version of an assignment submitted to the Department of General Linguistics at the University of Stellenbosch in 1997 in parial fulfilment of the requirements for the MA degree in General Linguistics. I wish to acknowledge the contribution of the Department and, in particular, that of Dr Johan Oosthuizen in supervising the work from which this article resulted. Neither the writing of this article nor my stay at the University of Stellenbosch would have been possible without the financial assistance I received from the 'Stichting VSB beurzen' in Utrecht, The Netherlands, and from the 'Stichting Neerlandia' in Bloemfontein, South Africa.

2 The traditional analysis of the verb movement in Dutch was pioneered by Koster (1975) and Den Besten (1977) among others. Two hypotheses were at the centre of this analysis. First that the underlying word order of Dutch is SOV, and second, that the Dutch finite verb moves invariably to C in tensed main clauses.
}

Stellenbosch Papers in Linguistics, Vol. 31, 1998, 95-124

doi: $10.5774 / 31-0-58$ 
view of the interaction between syntax and morphology. Finally, we will see how these proposals help to explain the word order asymmetry in subject initial main and embedded clauses and in inversion constructions.

\subsection{Dutch as an SVO language}

In his Morphosyntax of verb movement: a minimalist approach to the syntax of Dutch, $\mathrm{Zwart}$ argues for an alternative analysis to the traditional analysis of the word order variation in West Germanic subject initial main clauses and embedded clauses. This word order variation is exemplified in (1) for Dutch.

a. Peter leest het boek Peter reads the book

'Peter reads the book'

b. ik zie dat Peter het boek leest

I see that Peter the book reads

'I see that Peter reads the book'

In the subject initial main clause (la) the finite verb is in second position, whereas it is in clause final position in the embedded subject initial clause (lb). Zwart's analysis is based on the minimalist framework in general and particularly on a theory of movement and feature checking which will be presented later. He claims, firstly, that the Dutch phenomena in (I) can be profitably analysed as involving leftward movement only and, secondly, that 'a strict application of the minimalist principles leads to a simple and elegant analysis of the complicated functional domain in Dutch"3. In this section I will present Zwart's analysis and in the next section, consider whether it can also account for the word order variation found in Afrikaans.

Zwart's assumption of the underlying structure is based almost entirely on the restrictive approach to structure presented in Kayne (1994). Kayne proposes a theory of phrase structure

${ }^{3}$ (Zwart 1997:5) This can only be partly true as yet. Though the presented analysis for the verb movement asymmetry is of an elegant nature, Zwart does not apply it to constructions involving more than one verb. Its empirical merits for more elaborate verbal constructions is as yet not established. It will be shown later on in this article that Zwart's analysis in fact calls for a reanalysis of such verbal 
which assumes one universal SVO underlying word order ${ }^{4}$. Presenting conceptual arguments Kayne proposes that all projections look as follows.:

(2)

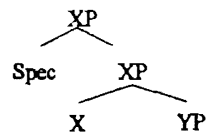

All other constructions are derived from this underlying basic structure strictly by leftward movement only. No rightward movement, which in this proposal would always be lowering, is allowed. Adjunction to a head is limited to left-adjunction.

\subsection{Double Agreement}

In arguing for the existence of AgrS-to-C movement in the languages under discussion, Zwart (1997) starts out from the double agreement in dialects of Dutch and Frisian. He shows that all dialects that have complementiser agreement show the word order asymmetry exemplified in (1). More importantly, Frisian, spoken in the north of The Netherlands, has complementiser agreement in embedded clauses, but only if the embedded clause has not been subject to overt verb movement (Zwart 1997:198). Consider the following examples in this regard:

a. Heit sei datst do soks net leauwe moast dad said that-2SG you such not believe must-2SG

b. Heit sei dat $/{ }^{*}$ datst do moast soks net leauwe dad said that that-2SG you must such not believe

'Dad said that you should not believe such things'.

Complementiser agreement is signalled in these Frisian examples by the complementiser datst (with dat being the neutral complementiser). In (3a) the finite verb moast is in sentence final position which, Zwart assumes, is the verb's base position $\mathrm{V}$, the object having moved to the left of this position. In (3b), however, the verb is in verb second position, to the immediate right of the subject. This is an instance of verb movement in an embedded clause. We can see from (3) that complementiser agreement and verb movement are in complementary distribution in Frisian embedded clauses. Zwart (1997:198-9) hypothesises from this observation that complementiser agreement must be AgrS-to-C movement, and that

\footnotetext{
${ }^{4}$ This is also know as the 'universal base hypothesis'.

5 The notation XP for X' reflects the proposals made in the literature for a 'two-level' X-bar structure (Hellan 1991, Hoekstra 1991, Kayne 1992 among others). It is assumed to reflect a fundamental property of phrase structure, namely the distinction between heads and phrases (Zwart 1997:8n, 175). Stellenbosch Papers in Linguistics, Vol. 31, 1998, 95-124

doi: $10.5774 / 31-0-58$
} 
(embedded) verb movement must be V-to-AgrS movement, assuming as a standard structure the sentence structure in (4).

(4)

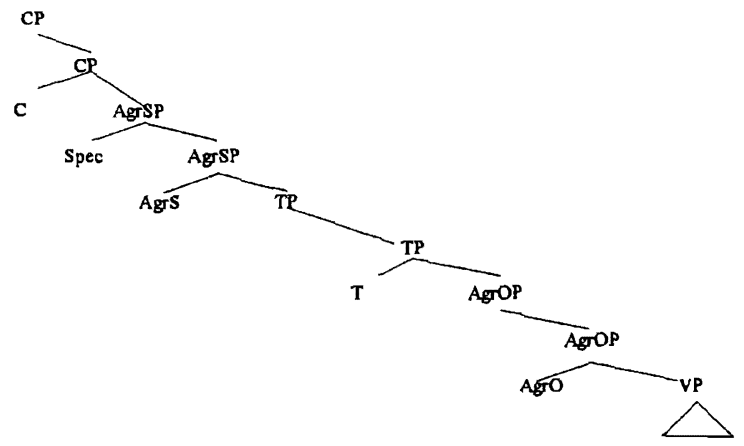

This makes AgrS the pivot of verb movement in West Germanic languages, and not C, as was the case in the traditional analysis ${ }^{6}$. Zwart then argues that not only Frisian but all complementiser agreement dialects have verb movement asymmetry (cf. (1)). This syntactic generalisation can be made without exception for all overt complementiser agreement morphology. Although Standard Dutch itself does not have overt complementiser agreement morphology Zwart concludes that it has overt AgrS-to-C movement as well, assuming that it only lacks a paradigm of inflected complementisers to show for it. This leads to the assumption that Standard Dutch does have abstract complementiser agreement.

\subsection{Feature Movement and the interface between syntax and morphology}

In addition to the assumption of AgrS as the pivot of verb movement in Dutch Zwart advances a proposal of feature movement (Zwart 1997:ch V). He bases this proposal on the definition of Feature Movement in Chomksy (1995:262) and on the concept of Distributed Morphology introduced by Halle and Marantz (1993). Chomsky's concept of feature movement was advanced as the most economical way to check formal features, that is, those features involved in feature checking operations (tense, agreement and case, for example). Halle and Marantz' Distributed Morphology, which is referred to as postlexicalism by Zwart, defines the relation between morphology and syntax. In their view, stems and morphemes are only bundles of formal and semantic features during the syntactic derivation. In postsyntactic

6 In the traditional analysis, Dutch was assumed to have an underlying SOV word order. The finite verb was assumed to move to the COMP, or C, position through V-to-C movement (Den Besten 1977, Stellenbosch Pdpetter ihPp Phiguistics, Vol. 31, 1998, 95-124 
morphology, i.e. in PF, these bundles are spelled out as lexical items. Zwart (1997:161-7) argues that postlexical morphology and the minimalist program are highly compatible.

Zwart's proposal is the following. Lexical elements are bundles of features that are spelled out in a postsyntactic component called morphology. Throughout the syntactic derivation semantic and syntactic features are present in these bundles. Phonological features are only added after Spell-Out and play no role in the syntactic derivation. In this proposal Zwart (1997:168-70) makes an important distinction between formal features (F-features) and lexical-categorical features (LC-features). F-features correspond to Chomsky's (1995) formal features and are those features that are involved in feature checking operations. LC-features contain semantic features and the categorial features [verbal] and [nominal]. Semantic features are involved in the identification of lexical items. Although only F-features are involved in checking operations they can only be spelled out at the Spell-Out point when paired with LC-features (Zwart 1997:182).

In the minimalist program features must be checked before the interface representations of LF and PF (Chomsky 1993, 1995) if the lexical item is to be spelled out. This checking is done by matching the features on the lexical items with features (V-features and $\mathrm{N}$-features) associated with functional heads. The matching is done by movement to the functional heads. When the $\mathrm{V}$ - and $\mathrm{N}$-features on the functional heads are strong they trigger 'overt' movement, i.e. movement before Spell-Out. Weak features only trigger movement after Spell-Out, which is in accordance with the Procrastinate principle. Another consequence of the minimalist approach is that only the formal features in the lexical feature bundle move overtly, since they are the only ones that need to be checked (Chomsky 1995:261f.) And because the overtly moved formal features cannot be interpreted in the morphology it is assumed that the other features follow in covert movement.

Zwart incorporates this analysis of feature movement in his analysis of verb movement asymmetry. He argues that strong V-features associated with functional heads trigger F-feature movement, or F-movement to the functional head. F-movement leaves the LC-features behind in the base position. When the verb movement is overt the presence of Fmovement alone will not be enough to spell out the verb in the higher position because the resulting structure is uninterpretable in PF. The LC-features have to move (LC-movement) overtly to join up with the F-features and to create an interpretable object. The LC-movement, in that case, is a Last Resort ${ }^{7}$ operation.

(See Chomsky 1993) A 'last resort' operation is applied when all other operations to avoid a

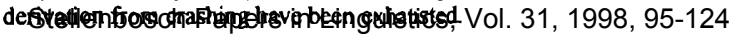

doi: $10.5774 / 31-0-58$ 
The input to the morphological component mentioned above is defined as a morphosyntactic complex. This is a head adjunction cluster containing the feature bundle. This feature bundle is referred to as the label of the complex (cf. Chomsky 1995:243). The morphosyntactic complex is formed in the course of the syntactic derivation by adjoining the verb features in $F(v)$ to the tense and agreement features in T and Agr. This cluster will look more or less like (5):

(5)

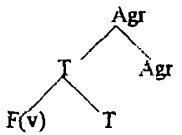

In Government and Binding theory, as presented in (Chomsky 1981), this would correspond to the following derivation: the stem of the verb is generated in $V$. This stem is adjoined to $T$, which contains a tense affix. The result of this is a complex of $\mathrm{V}+\mathrm{T}$ which in its turn adjoins to Agr, which contains an agreement affix, resulting in the structure in (5). Zwart (1997:160) refers to this as weak lexicalism, which differs from his present postlexical proposal in that the verb and its affixes are already represented on the heads ${ }^{8}$. In Zwart's proposal the features instead move to assign a feature value to the features in the lexical heads. This value assignment is done in a strict sisterhood relation: the F-features (in (5)) of the verb adjoin to the head $T$ in a sisterhood relation, thus assigning the values of the verb's $F$-features to $T$. The head $T$ in its tum passes on the $F$-fearures of the verb to its parent-node $T$. We say that the feature value 'percolates up' to become part of the label of the higher node (Zwart 1997:188). This process is repeated when the parent node is adjoined to a higher head. Thus, in (6) the value of the F-features of the verb percolates up all the way to the topmost node Agr. This topmost node is the label for the entire morphosyntactic complex.

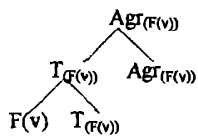

${ }^{8}$ Zwart distinguishes the following approaches to lexicalism: weak lexicalism, which makes a distinction between derivational morphology and inflectional morphology; strong lexicalism, which does not make this distinction, and postlexicalism, which differs from the other two in assuming that the syntax manipulates lexical items generated by the morphological component of the lexicon (Zwart 


\subsection{Embedded and Main Clause Verb Movement}

As we saw above Zwart hypothesises that, first, the verb moves to AgrS instead of to $\mathrm{C}$ and, second, the verb movement asymmetry results from an interaction of AgrS-to-C movement and V-to-AgrS movement. Feature movement is triggered by strong features on the functional heads. Zwart (1997:202) assumes that for Dutch both the $\mathrm{N}$-features and the Vfeatures of AgrS are strong. The strong $\mathrm{N}$-feature accounts for the movement of the subject to the specifier position of $\mathrm{AgrS}^{9}$. The strong $\mathrm{V}$-feature accounts for the movement of the Ffeatures of the verb to AgrS.

Zwart now makes the following assumptions. Feature checking is assignment of a value, and is constrained by a sisterhood condition. This means that the syntactic relation that is expressed by the F-feature (e.g. subject-of, object-of) must be checked in a sisterhood relation. The subject must therefore adjoin to AgrSP and the F-features of the verb must adjoin to AgrS. It is in this fashion that AgrS is assigned its value: the F-features move overtly, because the V-features of AgrS are strong, and the LC-features of the verb are left behind. This does not yet mean, as we will see, that the verb itself is actually spelled out in AgrS.

The F-movement to AgrS is not done in one step. Chomsky (1993:7) assumes AgrS and AgrO to be one Agr element. The strength on both Agr elements must therefore be equal, which means that overt movement to AgrS also implies overt movement to AgrO. Zwart (1997:203) concludes that F-movement proceeds stepwise via AgrO, and, since T also needs to be assigned a value via $T$ as well. This is in accordance with the Head Movement Constraint of Travis (1984) which prohibits head movement across a head. Zwart assumes this constraint to be operative in his analysis. Assuming all this, F-movement to AgrS will result in the following morphosyntactic structure(7):

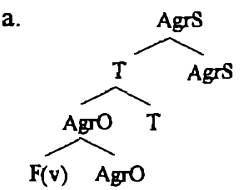

We can follow the sequence of the V-toAgrS movement by considering the structure in (7). The F-features of the verb, F(v), adjoin to AgrO, assigning its feature value there, which 
percolates up to the directly dominating node AgrO. F(v) and AgrO, which are now in a sisterhood relation under the higher $\mathrm{AgrO}$, move on and adjoin to $\mathrm{T}$ to assign a feature value there. The result of this second step, the topmost node T atop AgrO and T, moves to AgrS and adjoins there, creating the structure in (7).

Now we come to the final step in the derivation: AgrS-to-C movement. For movement to $C$ to be justified in minimalist terms we need a feature on a lower head that needs to assign a value to a feature in the head it moves to, which, in this case, is $\mathrm{C}$. Following Den Besten (1989:92) Zwart assumes this feature in $C$ to be Tense. According to Den Besten a clear interdependency exists between complementisers and finiteness in Dutch. Finite embedded clauses, for instance, have als, of, or dat as a complementiser (8a), whereas a non-finite embedded clause would have the complementiser om (8b).

a. als/of/dat/*om Jan Marie kust as/ if/ that/for to John Mary kisses

b. om/*als/*of/*dat Marie te kussen for to/ as' iff that Mary to kiss

The relation between the complementiser and tense is unidirectional: a particular complementiser requires a particular tense, but a particular tense does not necessarily require the presence of a particular complementiser. Zwart (1997:204) concludes that $C$ needs to be assigned a value for tense ${ }^{10}$, and will therefore have to attract the tense features of the verb. These are nested in $F(v) . C$ will therefore have to attract the complex resulting from V-toAgrS, the structure in (6). Movement of this complex to $C$ will yield (9). We now have the morphosyntactic result of the AgrS-to-C movement which $Z$ wart argues is characteristic of the word order asymmetry under discussion.

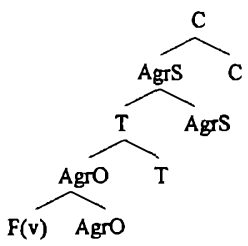

10 This is a crucial. assumption in Zwart's analysis. Without it the analysis would be useless. Unfortunately the assumption is not based on strong empirical arguments. Zwart himself summarizes the reason for the movement to $\mathrm{C}$ as 'presumably because $\mathrm{C}$ attracts $\mathrm{T}$, incorporated in AgrS [italics Stellenbosch Paperine ${ }^{-}$EVh' The proposeg analysis gyould benefit considerably if the attraction of $\mathrm{T}$ to $\mathrm{C}$ is doi: 10.5774/31-0-58 
Up till now, however, we have only considered movement of the F-features of the verb. The complex in (7) is morphologically uninterpretable, since morphology. can only attach a lexical item to F-features that are paired to LC-features. We saw that LC-movement is only triggered as a Last Resort operation to create a morphologically interpretable object. Otherwise LC-movement will be covert. To explain the absence of verb movement in Dutch embedded clauses $Z$ wart argues that in (9) the F-features combine with the LC-features in C to produce a morphologically interpretable object. The $\mathrm{LC}$-features are present in $\mathrm{C}$-since $\mathrm{C}$ is lexically filled. The complex in (9) will be spelled out as a complementiser carrying agreement inflection (overt or covert, depending on the paradigm of the language in question). The LC-features left behind in V need therefore not be moved as a Last Resort operation in (9). The verb is instead spelled out in $V$ where the $F$-features are still present in the form of a copy in the position of the trace resulting from F-movement (Chomsky 1993:35). This explains the word order asymmetry.

In subject initial main clauses the morphosyntactic complex does not move to $\mathrm{C}$. $\mathrm{AgrS}$ is the highest functional projection in these clauses and the result of F-movement in this case is equal to (7). The F-features in this morphosyntactic object lack the LC-features they need to be interpreted by Morphology. The LC-features of the verb will therefore be moved as a Last Resort. They adjoin to AgrS in (7) yielding (10):

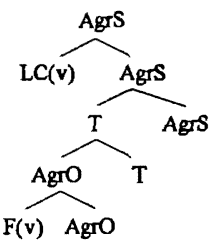

Both the F-features and the LC-features of the verb are now reunited in one object and can be spelled out by Morphology. In V we are left with two copies", one of the F-features and one of the V-features. It is unclear why Morphology does not spell out these copies as a verb. Zwart (1997:208) goes along with the general assumption that Morphology does not spell out more than one copy of LC-features and that it is the bighest copy that is spelled out ${ }^{12}$.

\footnotetext{
"Zwart assumes that at the base position of the moved element the trace left behind after movement is really a copy of the moved element. This is in accordance with Chomsky's copy theory of movement (Chomsky 1993:35).

${ }_{12}$ As was pointed out to me by Johan Oosthuizen, the presence of the lower copy is in fact supported by instances from earlier stages in the development of Afrikaans, where both copies are spelled out, i.e.

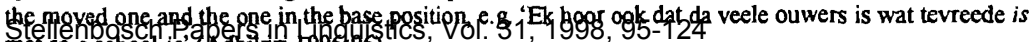
met so school is' (athikn 1998.96). 


\subsection{Inversion constructions}

The verb movement proposal presented so far can be used to analyse inversion constructions as well. Inversion constructions differ from subject initial main clauses in that the finite verb precedes the subject instead of following it (Zwart 1997:245):

a. Weer kust Jan Marie again kisses John Mary

'Again John kisses Mary'

b. Waarom kust Jan Marie?

Why kisses John Mary

'Why does John kiss Mary?'

Following Den Besten (1977) Zwart concludes that the finite verb in inversion constructions occupies the same position as the complementiser in embedded clauses, i.e. in $\mathrm{C}$. The highest functional projection in subject mitial main clauses is AgrSP. This means that there must be an extension of the tree up to $\mathrm{CP}$ in the case of inversion, and this extension must be triggered by a grammatical feature. This feature can either be a wh-feature, as in the case of $(11 \mathrm{~b})$, or a feature associated with topicalizations, as in (11a). This latter feature is referred to by $Z$ wart as d-feature (Zwart 1997:247). In both constructions in (11) we can assume that $\mathrm{C}$ carries the wh- or d-feature respectively. These features will check corresponding features on the fronted constituent, and the feature value will then percolate up to become part of the label of the sentence as a whole. Zwart accepts the analysis proposed in Hoekstra and Zwart (1994) that $\mathrm{CP}$ is in fact a combination of two non-L-related functional projections. These are WhP and TopP, and each provides a designated licensing position for wh-elements or d-words ${ }^{13}$, respectively. This structure will allow for the possibility of having the interrogative complementiser of and the noninterrogative complementiser dat combined in one construction, which is a grammatical sequence in Dutch ${ }^{14}$.

${ }^{13} \mathrm{D}$-words are demonstrative elements often inserted between the fronted element and the verb in topicalisation constructions like (11a) (cf. Koster 1978):

$$
\begin{aligned}
& \text { Jan (die) ken ik niet t 'John, I don't know' } \\
& \text { John that one know I not }
\end{aligned}
$$

These $d$-words agree in $\varphi$-features with the fronted element. Zwart proposes that the d-feature is in fact associated with the d-word, and not with the fronted constituent (the satellite) (Zwart 1997:248).

${ }^{14}$ E.g. a sentence like:

'Jan vroeg of dat ik haar kende'

Stellenbosch Papers in asked whether that her hastic , 95-124

doi: 10.5774/31-0-58 
The difference between inversion constructions and subject initial main clauses now follows from the analysis of verb movement advanced by Zwart. Recall that when $C$ is present, as we assumed for inversion constructions, the morphsyntactic complex resulting from V-to-AgrS moves on to $C$, yielding the morphosyntactic object illustrated in (9). This movement to $\mathrm{C}$ is again, as in embedded constructions, triggered by the need for $\mathrm{C}$ to be assigned a tense feature by $T$. Zwart now argues that contrary to embedded constructions, $C$ in inversion constructions does not contain the LC-features of the complementiser, which makes the morphosyntactic object in (9) uninterpretable for morphology. This triggers a Last Resort movement of the LC-features of the verb, which yields the following structure:

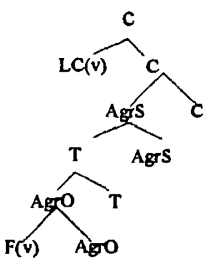

This structure will be spelled out by morphology as a verb, which explains the inversion of subject and the finite verb. This completes our survey of the main points raised in Zwart (1997). We will now turn our attention to Afrikaans.

\section{A look at Afrikaans}

Now that we have an idea of what Zwart's proposal entails we will consider whether it correctly predicts the grammaticality of all Afrikaans verbal constructions. We might expect this to be the case, since in ch. VI.5 Zwart puts forward the hypothesis that AgrS-to-C movement explains verb movement asymmetry in all Germanic languages that display it, and, conversely, that the absence of such an asymmetry ought to follow from the lack of AgrS-to$\mathrm{C}$ movement. This claim predicts that since Afrikaans is a Germanic language, ${ }^{15}$ the verb movement phenomena in Afrikaans are also a result of $\mathrm{V}$-to-AgrS and AgrS-to-C movement. Let us follow Zwart's argumentation for the applicability of the verb movement analysis to the other Germanic languages and see whether the same indeed holds for Afrikaans.

\footnotetext{
is I ignore here the unresolved and ongoing debate about the 'status aparte' of Afrikaans in the sense that its creolide history eroded its Germanic character to such an extend as to disqualify it as a purely Germanic language (for this matter see: Den Besten 1986, 1989, Raidt 1983). In this paper I will treat

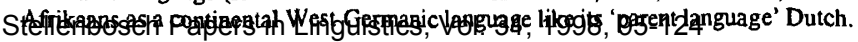

doi: $10.5774 / 31-0-58$ 


\subsection{Afrikaans as a Germanic language}

Recall that Zwart argues that the presence of AgrS-to-C movement is signalled morphologically as complementiser agreement in several languages and dialects, including Frisian, as exemplified in (3). The fact that Frisian only displays complementiser agreement in embedded clauses when there is no overt verb movement is indicative of a complementary distribution of complementiser agreement and verb movement (Zwart 1997:198). From this Zwart makes the generalisation that all languages that lack embedded verb movement must have AgrS-to-C movement, even though they might lack a complementiser agreement paradigm to show for it. It is assumed that the absence of such a paradigm is a superficial phenomenon and does not in fact mean that this would affect the syntax of such dialects or languages. The assumption is therefore made that abstract complementiser agreement is present in these languages.

Two preconditions for the presence of overt complementiser agreement in a language were formulated in Hoekstra (1992). The first precondition is that the nominal plural forms and the verbal plural forms must be identical, and the second precondition is that there must be a morphological opposition between singular and plural forms in the verbal paradigm. These preconditions are not met for Afrikaans: although Afrikaans has plural inflection for nouns, the verbal paradigm lacks such an inflection, neither is there a morphological opposition between singular and plural in the verbal paradigm. This paradigm, in fact, contains only one form for all persons and numbers. This rightly predicts the absence of overt complementiser agreement in Afrikaans. This does not automatically mean that Afrikaans has covert complementiser agreement instead. One could therefore not conclude that AgrS-to-C takes place in Afrikaans solely because 'the AgrS-to-C hypothesis provides a satisfactory account of the verb movement asymmetry in this language', although Zwart does so for the Mainland Scandinavian-Frisian languages (Zwart 1997:230). The generalisation that AgrS-to$\mathrm{C}$ movement takes place in all Mainland Scandinavian-Frisian languages is based entirely on observations from the other Germanic languages but has no direct empirical justification in data from Afrikaans ${ }^{16}$. We will see as well that unlike Dutch, Afrikaans is not a clear member of the Mainland Scandinavian-Frisian group of languages, since it does not share all the characteristics of that group. For the moment, however, we will go along with Zwart's argumentation.

Afrikaans in general lacks verb movement in embedded clauses, and, in the overriding number of cases behaves the same as Dutch, the West Germanic language it

${ }^{16} \mathrm{Zwart}$ bases this generalisation on the work presented in Latridou and Kroch (1992) and in Hooper and Thomson (1973). This work discusses the position of the finite verb in embedded clauses of West

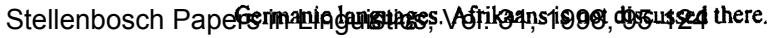


descends from. The Dutch sentences in (1), for instance, translate without any change in word order into Afrikaans:

a. Pieter lees die boek Peter reads the book

'Peler reads the book'

b. Ek sien dat Pieter die boek lees

I see that Peter the book reads

'I see that Peter reads the book'

Following Zwart, we would conclude that Afrikaans has abstract complementiser agreement and therefore lacks AgrS-to-C movement in embedded clauses. There are, however, a number of cases in which Afrikaans has embedded verb second, which makes classification of Afrikaans in the Germanic language group problematic. But before we have a look at some concrete examples of embedded verb second we will first consider Zwart's classification of embedded verb second languages.

Following Vikner (1995) Zwart distinguishes two types of embedded verb movement in Germanic languages. One is the Yiddish-Icelandic type, which consistently moves verbs in all embedded clauses, and the other is the Mainland Scandinavian-Frisian ${ }^{17}$ type, which only moves the embedded finite verb in specific circumstances. With embedded verb movement occurring only in certain situations Afrikaans would thus, at first glance, best fit in with the Mainland Scandinavian-Frisian type. Yiddish-Icelandic is described as a type that never has AgrS-to-C movement in overt syntax. The Mainland Scandinavian-Frisian type, in contrast, does have AgrS-to-C movement in overt syntax, except where verb movement takes place. For Mainland Scandinavian and Frisian Zwart (1997:234ff.) distinguishes the following contexts in which embedded verb movement takes place. (We will see presently whether these are the same contexts as the embedded verb movement contexts in Afrikaans.) The most important context in Mainland Scandinavian seems to be in the complement of bridge verbs, as in (14):

Pyt sei dat hy hie my sjoen

Pete said that he had me seen

'Pete said that he had seen me'

Bridge verb constructions are basically the contexts in which English allows embedded root phenomena (Zwart 1997:235). Embedded clauses with root phenomena contain the assertion 
of the sentence as a whole and, contrary to other, 'normal', sentences, where the assertion is contained in the matrix clause, this assertion is found in the embedded clause ${ }^{18}$ (cf. Hooper and Thompson 1973, latridou and Kroch 1992). Put more simply, the embedded clause or AgrSP qualifies as a full main clause, although it is introduced by a complementiser. Zwart argues as follows. We can assume that AgrS-to-C movement does not take place in these assertive embedded clauses. The reason for this is that the embedded clause need not be marked as dependent on the matrix clause. AgrS-to-C movement would mark AgrS as dependent on $\mathrm{C}$ (by assigning a tense value to $\mathrm{C}$ ).

Zwart, with Iatridou and Kroch (1992), also distinguishes the following contexts in which embedded verb movement is excluded in Mainland Scandinavian-Frisian (Zwart 1997:234):

(15) a. Pyt betreuret/betwifelet/leau net dat hy mie sjoen hie Pete regrets/doubts/believes not that he me seen has 'Pete regrets/doubts/believes not that he saw me'

b. "Pyt betreuret/betwifelet/leau net dat hy hie mie sjoen Pete regrets/doubts/believes not that he has me seen

c. Pyt woe sizze dat hy mie sjoen hie Pete wanted say that he me seen had

'Pete wanted to say that he saw me'

d. *Pyt woe sizze dat hy hie mie sjoen Pete wanted say that he had me seen

e. Wrijven helpt niet als je maagpijn hebt rubbing helps not if you stomach ache have

'Rubbing doesn't help if you have a stomach ache'

f. *Wrijven helpt niet als je hebt maagpijn rubbing helps not if you have stomach ache

${ }^{18}$ This construction typically allows for 'complement preposing', where the matrix clause and the embedded clause can be switched (Zwart 1997:236):

a. Piet zei dat hij kende dat boek niet Pete said that he knew that book not

'Pete said that he did not know that book'

b. Hij kende dat boek niet, zei Piet He knew that book not said Pete 'He did not know that book, Pete said'

(The example in a. is provided by $Z$ wart, and is claimed to be colloquial Dutch. To my ear, however,

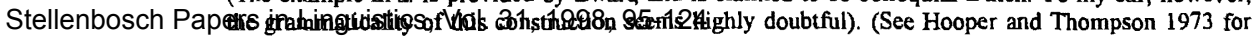
doi: $10.5774 / 31-0-58$ re on root phenomena). 
g. Dat Jan dat boek kent is verrassend that John that book knows is surprising

'That John knows that book is surprising'

h. *Dat Jan kent dat boek is verrassend that John knows that boek is surprising

(15)a exemplifies the complements of negative verbs like 'regret' or 'doubt' and negated verbs. Embedded verb movement is not grammatical in these cases $((15) b)$. Neither is embedded verb movement grammatical in irrealis complements $((15) c,(15) \mathrm{d})$, in adjunct clauses ((15)e, (15)f) or in sentential subjects ((I5)g, (15)h).

In her dissertation Robbers points out that for these contexts the situation is rather different for Afrikaans (Robbers 1997:28-32). Not all the contexts mentioned in (15) that constitute restrictions on embedded verb movement in Mainland Scandinavian-Frisian languages are similarly restrictive for Afrikaans. Consider the following sentences taken from Robbers (1997):

(16) a. Ek ontken dat ek het dit gedoen I deny that I have it done

'I deny that I did it'

b. Ek sou sê dat dit is heeltemal reg I would say that it is completely right 'I'd say that it is completely right'

c. As jy wil een hê, kan jy maar vra If you want one have, can you but ask

'If you want one, you can ask'

d. Dis goed jou pa het nie gehoor nie It-is good your dad has not heard NEG

It is good your dad did not hear it'.

*Jou pa het nie gehoor nie, is goed Your dad has not heard not, is good

e. Jy weet wie (*dat) moet ek in jou plek aanstel you know who (that) must $I$ in your place appoint

'You know who I must appoint in your place'

As we saw in (15) embedded verb movement is not allowed in Mainland Scandinavian in the complement of negative and negated verbs, in irrealis complements, adjunct clauses and sentential subjects. In (16) a rather different picture emerges. Verb movement in the complement of negative verbs is allowed in Afrikaans ((16)a). So is verb movement in irrealis Stellenbosch Papers in Linguistics, Vol. 31, 1998, 95-124

doi: $10.5774 / 31-0-58$ 
contexts $((16) b)$. Verb movement in adjunct clauses is also widely used, especially when introduced by dat-type complementisers like dat 'that', noudat 'now that', sodat 'in order to', etc., but also by other complementisers like as in $((16) c)$. Sentential subjects, finally, do not allow embedded verb movement in Afrikaans, as is evident from $((16) d)$. We see now that Afrikaans agrees with Mainland Scandinavian-Frisian on only one of the four embedded verb movement situations illustrated.

To summarise, Afrikaans does not meet Hoekstra's preconditions for the presence of overt complementiser agreement, and should therefore have, according to Zwart (1997), covert AgrS-to-C movement. The presence of AgrS-to-C in Afrikaans would qualify it as a member of the Mainland Scandinavian-Frisian group of Germanic languages. However, Afrikaans differs markedly on the contexts in which embedded verb movement is allowed. This, however, need not necessarily hamper the applicability of the analysis on Afrikaans verbal constructions. So let us now look at the actual Afrikaans embedded verb second clauses and see whether they are correctly predicted by Zwart's analysis.

\subsection{Embedded verb second}

Embedded verb second constructions have long been attested in Afrikaans and are frequently mentioned in the literature. It is especially common to find embedded verb movement in clauses that are not introduced by a complementiser. Consider for instance (17):

(17) Ek weet hy het die boek gelees

I know he has the book read

'I know he has read the book'

The sentence in (17) is reminiscent of the bridge verb constructions mentioned above (cf. $((16) \mathrm{a},(16) \mathrm{b})$. The difference here is that the complementiser introducing the embedded clause is not overt, or even totally absent. These sentences can easily be analysed by assuming that the subordinate clause does not project up to the CP level. In that respect, it can be regarded as a normal subject initial main clause with an AgrSP as its highest functional projection. There is no $\mathrm{C}$ to attract $\mathrm{T}$ and thus trigger AgrS-to- $\mathrm{C}$ movement. The LC-features will be moved to AgrS as a last resort and the finite verb is spelled out in AgrS.

Embedded verb movement also occurs in embedded clauses introduced by a complementiser: 
(18) Sy filosofie is dat ons aanvaar dinge his philosophy is that we accept things

'His philosophy is that we should accept things'

Zwart's analysis would predict that in cases such as (18) no overt AgrS-to-C takes place, which would again trigger last resort movement of the LC-features of the verb. Zwart (1997:233ff.) argues that AgrS-to-C movement is the process that lifts the barrier status of the complement, i.e. the clause is made transparent. Absence of AgrS-to-C therefore would make the embedded clause non-transparent. Zwart assumes that in Yiddish and Icelandic AgrS does not move to $C$ in overt syntax, but in covert syntax. For Mainland Scandinavian-Frisian Zwart assumes that in embedded verb second clauses AgrS moves neither in overt nor in covert syntax. The obvious question is why in these cases $\mathrm{C}$ need not attract $\mathrm{T}$ through AgrS-to-C.

Zwart claims that the lack of this need to attract $T$ should be ascribed to the contexts that allow or do not allow embedded verb movement in Mainland Scandinavian-Frisian. These are the contexts exemplified in (15) and (16) above. Zwart (1997:236-7) argues that in these contexts there is no need for $C$ to attract $T$ because the embedded clause is a root clause, i.e. it has the characteristics of an independent main clause, though introduced by a complementiser and functioning as an embedded clause. This does not explain, however, why some of the same contexts that do not allow verb second in Mainland Scandinavian-Frisian do allow verb second in Afrikaans (cf. (15) and (16)). Considering this issue and recalling the lack of complementiser agreement in Afrikaans it would seem that it is impossible to establish independently whether $C$ does ever attract $T$ in Afrikaans.

Embedded verb second in Afrikaans is, however, more diversified than would appear from (17) and (18). Besides the root phenomena or bridge verb contexts there are a number of other embedded verb second situations that apparently do not occur in the Mainland Scandinavian-Frisian type languages. Consider the following Afrikaans embedded verb second clauses taken from various sources (Ponelis 1993, Feinauer 1989, Oosthuizen 1996):

a. Ek wonder wat doen hy.

1 wonder what docs he

'I wonder what he is doing'

b. Ek wil uitvind met wie het Marie gesels

I want out-find with whom has Mary talked

'I want to find out with whom Mary has talked'

c. Ek het gewonder of sal hy kom

I have wondered whether will he come

'I have wondered whether he will come'

d. Ek weet nie of kan die bos miskien weer lewendig word nie

I know not if can the forest maybe again alive become NEG

'I do not know whether the forest could become revived again'

Stellenbosch Papers in Linguistics, Vol. 31, 1998, 95-124

doi: $10.5774 / 31-0-58$ 
e. Dit is vir die dag wat jy kan iets wegsit this is for the day that you can something put-aside 'This for the day that you'll be able to put something aside'

f. Dis by onse plaas wat my pa het vir hulle gesê, hulle moet loop this-is at our farm that my dad has to them said they must walk 'It was at our farm that our dad told them to go away'

g ...dat sy graag sal die boek wil lees ...that she eagerly will the book want read

'...that she will eagerly want to read the book'

h ...dat sy nie sal die boek wil lees nie ...that she not will the book want read NEG

'...that she won't want to read the book'

(19)a and (19)b are instances of embedded wh-clauses with verb movement. Besides whquestions, yes-no questions can also appear as embedded verb movement clauses, as in (19)c and (19)d. (19)e and (19)f are examples of relative clauses with verb movement and (19)g and (19)h, finally, are instances of open finals, which, as we will see further on, differ from embedded verb second clauses but are not predicted by Zwart's analysis. Let's discuss the sentences in (19) one by one.

Zwart suggests the following description of embedded verb movement (Zwart 1997:231). As in subject initial main clause verb movement constructions and subject initial embedded clauses both the $\mathrm{N}$-features and the $\mathrm{V}$-features of $\mathrm{AgrS}$ are strong. This triggers movement of the subject to the specifier position of AgrS and movement of the F-features of the verb to the head position of $\mathrm{AgrS}^{19}$. Contrary to subject initial embedded clauses with the finite verb in final position, however, $\mathrm{T}$ is not attracted by $\mathrm{C}$ and the morphosyntactic complex will remain in AgrS. So will the F-features of the verb. No overt AgrS-to-C movement takes place. The LC-features of the verb are therefore forced to move as Last Resort to provide the stranded F-features in $\mathrm{AgrS}$ with a morphologically interpretable object as they would do in subject initial main clauses. As a result, the verb is spelled out in AgrS, the verb second position, and we have a verb second embedded clause as a result.

The embedded questions in ((19)a - (19)d) are all instances of embedded inversion constructions. In each of the embedded clauses the finite verb precedes the subject. Zwart's analysis of inversion constructions would predict that due to the inversion the finite verb is expected to be in $\mathrm{C}$, but the fact that the clause is embedded would have to result in the complementiser being spelled out in $\mathrm{C}$. The question naturally presents itself whether in these situations $T$ is attracted by $C$. Zwart's analysis predicts that it is not possible to embed an

\footnotetext{
${ }^{19} \mathrm{Zwart}$ leaves it open whether or not movement of the subject and object involves scparate F- and LCmovement as well.
}

Stellenbosch Papers in Linguistics, Vol. 31, 1998, 95-124

doi: $10.5774 / 31-0-58$ 
inversion construction. Clearly Zwart's analysis makes the wrong prediction here. Let's see if we can find a way out. Consider the structure underlying sentence (19)c as illustrated in (20):

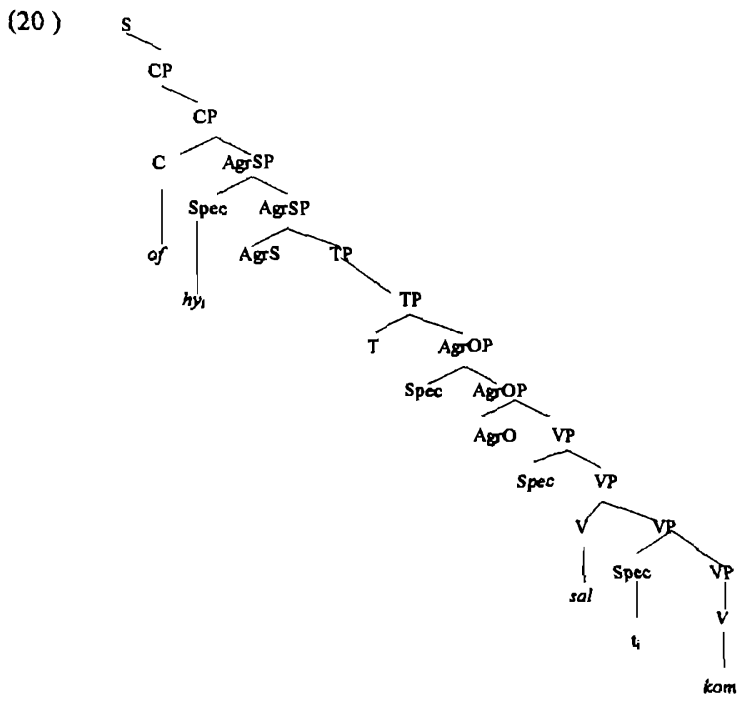

Only the structure of the embedded clause is represented. In this clause the subject hy moves to the specifier position of AgrSP, triggered by the strong N-features on AgrS. The subject is thus in a position where it can be licensed, i.e. in a sisterhood relation with the projection of the functional head AgrS. C contains the F- and LC-features for the complementiser of. The F-features of the finite verb sal move to AgrS as V-to-AgrS movement. Note now that if we assume that inversion takes place in the embedded clause, this would mean that movement of the morphosyntactic complex in AgrS would have to be triggered by the lack of LC-features in C. In our example (19c), however, the presence of the complementiser of means that $\mathrm{C}$ is furnished with LC-features, thus blocking inversion. Neither could we have the complementiser and the finite verb being spelled out in the same position. We would need an altemative position between $\mathrm{C}$ and $\mathrm{AgrS}$ for the inverted finite verb to be spelled out.

One way out might be to assume that $\mathrm{CP}$ is in fact a composite of the two functional projections $\mathrm{WhP}$ and TopP, as suggested earlier. The interrogative complementiser of in that case would have to find itself in the head position of WhP and the inverted verb would have to be spelled out in TopP. According to Zwart strong support for this division of CP into $\mathrm{WhP}$ and TopP is provided by the fact that in Dutch the interrogative complementiser of and the noninterrogative complementiser dat can be combined in one construction:

Stellenbosch Papers in Linguistics, Vol. 31, 1998, 95-124

doi: 10.5774/31-0-58 
(21)

Ik weet niet of dat er werk zal zijn

I know not whether that it work shall be

'I don't know whether there will be work'

This is possible for Dutch, as shown by (21), but the same is not grammatical in Afrikaans, as is evident in (22).
* Ek weet nie of dat daar werk sal wees nie
I know not whether that there work shall be NEG
'I don't know whether there will be work'

This sheds some doubt on the existence of the 'double' CP for Afrikaans: Oosthuizen (1996:92), however, considers the combination of an interrogative and a non-interrogative complementiser a possibility in non-standard forms of Afrikaans. The complementiser dat can only be spelled out in the head position of TopP when no inversion takes place in the embedded clause (cf. sentence (16)a) ${ }^{20}$ :

\footnotetext{
${ }^{20}$ The grammaticality judgements that I gathered indicate that a sequence of wh-words like wat, dat, waar and the complementiser dat is grammatical in Afrikaans (cf. (23a)), but that the sequence of dat is not grammatical. This would suggest that we are in fact dealing with the single lexical item ofdat, which, though a Dutch lexical item, is not part of the lexicon of Afrikaans. This would be in contradiction with the argument in Hoekstra and Zwart (1994) that the Dutch of dat comprises two lexical items and not one. They try to show this by applying conjunction reduction (Hoekstra and $Z$ wart 1994:193):
}

a. De jurk is ver-maakt en ver-knipt

*De jurk is ver-[maakt en -knipt]

b. Hoewel hij jong is en hoewel hij weinig eet

*hoe-[wel hij jong is en -wel hij weinig eet]

c. Ik weet waarom of-dat je komt en ofdat je zo vroeg weer weggaat

Ik weet waarom of-[dat je komt en -dat je 20 vroeg weer weggaat]

Hoekstra and Zwart argue that lexical items that form one head and not two cannot be split in a conjunction construction. In (a) the second prefix ver- cannot be deleted. This proves, it is argued, that the verbs vermaken and verknippen are one lexical head and cannot be split. The argument is similar for the complementiser of dar: Zwart and Hoekstra argue that because this complcmentiser is in fact a combination of two lexical heads it is possible to delete the first part in the second clause of the conjuction construction, as is shown in (c). This will not produce an ungrammatical construction. What Hoekstra and Zwart fail to point out, though, is the fact that in (c) we might just as well be dealing with two different lexical items, one being ofdat and the other dat, each introducing one of the conjuncted clauses. The conjunction constructions above, therefore, can hardly be seen as convincing evidence for the existence of two lexical heads in ofdat. The ungrammaticality of Afrikaans ofdat in (22) would 
(23)
a. Ek wil weet wat dat hy doen.
b. *Wat dat doen hy?
c. *Ek wil weet wat dat doen hy.

This complementary distribution of the complementiser and the inverted finite verb in (19)a and (23) suggests that both are spelled out in the head position of $\mathrm{TopP}^{21}$. If we were to assume the existence of a double CP for Afrikaans, however, we would still not be able to explain why a sentence like (24) is also possible in Afrikaans (Oosthuizen 1994:167):
My gevoel is dat het dit maar so gebeur!
my feeling is that has this but so happen
'My feeling is that if only things had happened that way!'

So far the Afrikaans embedded inversion constructions we have seen here introduced by a wh-word like of, but the embedded inversion construction in (24) is introduced by a noninterrogative complementiser dat. Even when we assume the existence of the double complementiser position we cannot accommodate both the complementiser and the inverted finite verb. We would have to assume both to be positioned in the head position of TopP. This we cannot do.

Neither would we be able to explain why the embedded inversion in (19c) is allowed in Afrikaans but not in Dutch while we still assume the same underlying structure. This is a clear problem to which $I$ have no immediate answer, although one might consider the possibility of maintaining a single CP besides the presence of a double CP consisting of a WhP and a TopP. One would in such a case have three positions availabe: WhP, TopP and CP. In the case of (24), the inverted finite verb would move to CP and the complementiser would be spelled out in TopP. The difference between Dutch and Afrikaans could then possibly be explained by assuming that the extra $\mathrm{CP}$ is a feature solely of Afrikaans, and not of Dutch. This assumption of an extra $\mathrm{CP}^{22}$, however, demands extra research beyond the scope of this article.

\footnotetext{
${ }^{21}$ Den Besten (1989:160) even mentions the existence of the sequence of a wh-word, a complementiser and an inverted finite verb:

...hoekom dat het hy dit gedoen

why that has he it done

'... why he has done if'
}

This construction, however, is rare in Afrikaans and is considered 'very low', according to Den Besten. Stebill leave it put of consideration in this discussjon $1998,95-124$ doi: $10.5774 / 31-0-58$ 
The last instance of embedded verb movement in Afrikaans, the relative clause as exemplified in (19e) and (19f) does not present any real problem. The analysis here is similar to that presented for (18), the clause introduced by a complementiser with the finite verb in AgrS. We can similarly assume here that the relative complementiser wat in both sentences does not attract the Tense features in AgrS. AGRS-to-C will not take place, the LC-features of the verb move as a Last Resort and the finite verb is spelled out in AgrS.

\subsection{Open finals}

To round off the survey of embedded verb second in Afrikaans we will have a cursory look at a phenomenon related to embedded verb movement constructions. Recall the as yet undiscussed Afrikaans sentences in (19)h and (19)i. This Afrikaans construction is unknown in Dutch and is presented as an open final construction in Ponelis (1993:331). In this construction the verbal cluster at the end of an Afrikaans sentence can be interrupted by the object or other non-verbal material. This is not possible in Dutch. Consider the following example sentences:

a. Sy sal graag die boek wil lees she will eagerly the book want read

b. Sy sal nie die boek wil lees nie she will not the book want read NEG

c. Sy sal die boek nie wil lees nie she will the book not want read NEG

d. Sy sal graag wil die boek lees she will eagerly want the book read

e. ... dat sy graag die boek sal wil lees that she eagerly the book will want read

f. ...dat sy graag sal die boek wil lees that she eagerly will the book want read

g. ...dat sy nie sal die boek wil lees nie that she not will the book want read NEG 'she would like to read the book'

'she won't want to read the book'

'she won't want to read the book'

'she would like to read the book'

'...that she would want to read the book'

'...that she would want to read the book'

'...that she will not want to read the book'

It must be noted that these examples will not be considered equally grammatical by all speakers of Afrikaans. Their occurrence varies widely amongst the different varieties of the language, but the construction has a long standing history in the development of Afrikaans. (See Ponelis (1993) for more details.) Notice that when the open final occurs in an embedded construction, as in $((25) \mathrm{e}-(25) \mathrm{g})$, the finite verb may appear to be in second position. There 
Often these two constructions can appear the same, but in open finals the finite verb and the subject may be separated, as in (25)f by an abverbial, or by negation as in (25)g. The term "open final" refers to the fact that a final string of verbs in the clause can be broken up by non-verbal material.

The question that comes to mind in the light of our discussion so far is whether this construction involves movement of the finite verb to AgrS or whether it remains in $V$. Consider the underlying structure for the sentences that have an adverbial element between the subject and the apparently moved finite verb, such as $(25) \mathrm{g}$, here illustrated in $(26)^{23}$ :

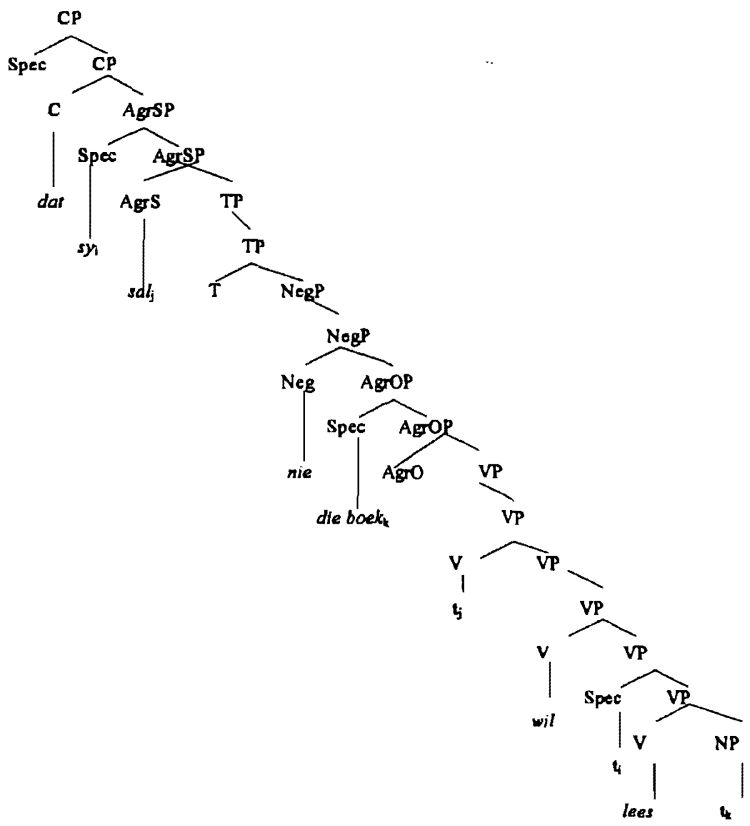

The structure in (26) represents the situation as it would be in a normal embedded verb second situation. The subject sy has moved to [Spec, agrS]. The object die boek has moved to [Spec, AgrO] and the finite verb sal is spelled out in AgrS due to Last Resort movement of the LCfeatures of the verb. 
In the case of (25)g the finite verb sal must have moved, since it appears to the left of the object die boek in [Spec, AgrO]. If we assume, however, that the finite verb moved to AgrS, as Zwart's analysis demands, we would have to account for the fact that there is no position for the negator to move to. No position between the subject in [Spec, AgrS] and the finite verb in AgrS is available. Note also that we would need to identify a trigger for the movement of the negator. Zwart (1997) offers no immediate solutions to these problems.

\subsection{Past participles and verbal clusters}

For simple main and embedded clauses containing one finite verb Zwart's analysis seems to work quite well. But things become more complicated when we start to consider more complex verbal phenomena which involve infinitives and past participles. Consider the following sentences:
a. ...dat sy die boek gelees het
b. ...dat sy het die boek gelees
c. *...dat sy die boek het gelees

(27)a is an instance of an embedded sentence that lacks overt verb movement. The finite verb is in its base position. (27) b is an instance of embedded verb second. The finite verb has moved to AgrS. Following Zwart's analysis, we assume that the finite verb, the auxiliary het in this case, is spelled out in its base position in the embedded clause, because its F-features have moved first as V-to-AgrS to the head-position of AgrSP and subsequently to $\mathrm{C}$ as part of AgrS-to-C movement. The F-features combine with the LC-features in $\mathrm{C}$ and are spelled out as the complementiser dat. The LC-features of the verb remain behind in the base position of the verb and are spelled out together with the left-behind copy of the F-features. Zwart's analysis works well for clauses with single finite verbs, but when we add a past participle we get unexpected results. For (27)a we would in fact expect the order in (27)c, where the finite auxiliary precedes the participle, since $Z$ wart assumes that these constructions involve two VPs, with the auxiliary in the higher VP and the participle in the lower one (Zwart 1997:241). It might seem, then, that Zwart (1997) makes the wrong prediction for Afrikaans embedded clauses containing a past participle and auxiliary.

Note that the order of the verbs in (27)c is grammatical for the Dutch counterpart '...heeft gelezen', but Zwart's (1997) analysis on its own would still fail to produce the other order, '...gelezen heeft'. If we want to maintain Zwart's analysis that the finite verb does not 
move in the embedded clause, then we have to conclude that the past participle was moved to the left of the auxiliary.

In earlier publications Zwart tried to account for word order variation in verbal clusters (Zwart 1993, 1995). In his Syntax of Dutch (1993) Zwart attempts to analyse the verb cluster variation in both an SOV and an SVO framework. He concludes that the SVOhypothesis can make do with a simpler set of rules than the SOV-hypothesis and that it provides a more elegant analysis. Let us take a short look at the proposals in $Z_{\text {wart }}$ $(1993,1995)$ which focus on the SVO hypothesis.

In the (1993) SVO-analysis Zwart assumes that the VPs in the VP-cluster can optionally expand their functional projection up to the AgrOP level (Zwart 1993:345):

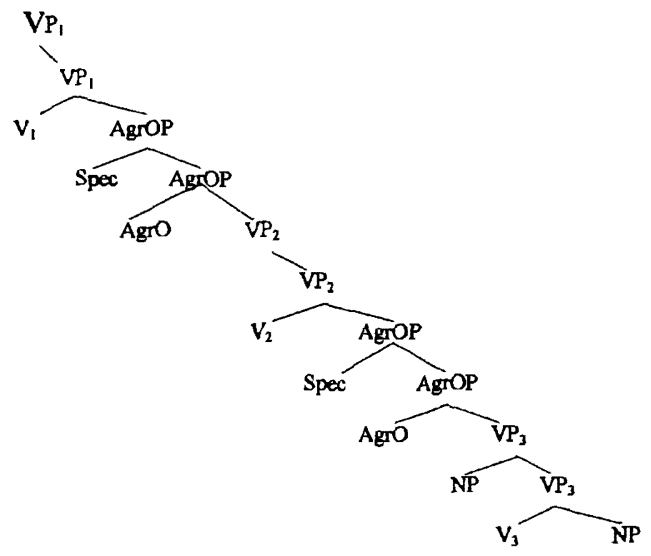

Just on top of the highest VP Zwart furthermore assumes the existence of a PredP, a predicate phrase $^{24}$. The lowest VP, $V_{3}$, contains the infinitive, $V_{2}$ the auxiliary and the highest VP, $V_{1}$ would contain any modal verb. Variation in the verbal cluster is achieved by raising any of the lower verbs to adjoin to a higher verb. This adjunction is invariably left-adjunction in the SVO-hypothesis (see Kayne 1994) The optional expansion of any of the VPs with an AGrO projection furthermore helps to generate any possible word order in the verbal cluster, including such constructions as extraposition, verb raising and verb projection raising (see Zwart 1993:345 for details). The object can move from its base position in the lowest VP to any of the [Spec, AgrO] positions in the VPs to create alternative constructions.

\footnotetext{
${ }^{24}$ See Zwart (1993:326ff.) Zwart argues for the existence of a Predicate Phrase between AgrOP and the topmost VP on the basis of data about the positioning of Small Clause predicates. These predicates appear invariably to the left of the verb in embedded clauses. Assuming that Dutch is head-initial this means that these small clause gredicates cannot be in their base position and must therefore be in a licensing position. Zwart assumes this

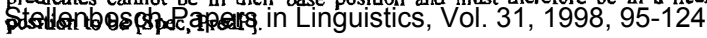


This analysis of verbal clusters is abandoned in Zwart (1995) in favour of another analysis. In that work $\mathrm{Z}_{\text {wart }}$ formulates two processes that are assumed to cause word order variation in Continental West Germanic (Zwart 1995:216):

Movement in verbal clusters:

a. Adjunction of an infinitival verb to a modal verb ( $\mathrm{X}^{0}$-movement ).

b. Raising of a participle to the specifier position of an auxiliary verb (XPmovement) ${ }^{25}$.

Zwart (1995) argues that infinitives undergo head movement and are licensed by adjunction to the immediately higher verb. Participles undergo XP-movement and are licensed by movement to the specifier position of an auxiliary verb. The latter process can be extended by moving the participle to the specifier position of a modal verb which an infinitival auxiliary has been adjoined to (see Zwart 1995 for details).

Both of Zwart's earlier proposals for the analysis of verbal clusters suffer from one significant drawback when incorporated in the verb movement analysis in Zwart (1997). All the movement operations suggested in both Zwart (1993) and Zwart (1995) are incompatible with the principles of the general base hypothesis adopted in Zwart (1997). In this hypothesis movement must be triggered by a feature checking requirement and verb movement must be head-to-head movement. Consider the morphological structure of the participle: consistency would demand that similar to the finite verb, a morphosyntactic structure functions as the input to the morphological component for the past participle as well. This means that there must be F-feature movement and LC-movement for the participle as well. One could think of a [ \pm perfect] feature as a trigger for the licensing of the past participle.

The point that needs to be made in connection with the subject of this article is that Zwart's analysis might account for word order asymmetry but also triggers the need for a reevaluation of the analyses proposed so far for the more complex verbal clusters. One would also have to consider the consequences for Zwart's verb movement proposal when introducing a new structure, like the PredP introduced in Zwart (1993). What would be the consequences for the morphosyntactic complex resulting from F-movement? Would it include

\footnotetext{
${ }^{25}$ Zwart argues that if participles are licensed in specifier positions, and specifier positions are always to the left, there is no way in which a cluster consisting of an auxiliary and participle (e.g. Dutch heeft gewerkt, "has worked') could be derived starting from a head final structure. Zwart considers this to be a strong support for the assumption of a head initial structure as the basic structure for multi-verb constructions in all Germanic languages (Zwart 1995:225). Considering Afrikaans however, we can argue for an el oppasitum: the same word order is ungrammatical in Afrikaans verb clusters (i.e. "het gewerk, "has worked' does not occur in embedded clauses) Exccpt for a main clause sentence like $e k$ het gewerk, 'I have worked' (which is a sentence that is explained by the verb movement analysis in Zwart 1997), the auxiliary will always follow the participle in Afrikaans. Combining

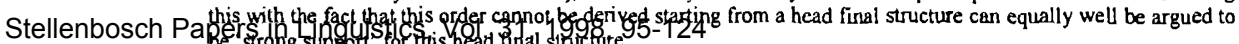
doi: 10.5774/31-0-58 
movement to the new XP, i.e. would the head Movement Constraint (Travis 1984) be observed?

Acceptance of Zwart's proposal clearly triggers the need for the re-evaluation of much of the data involving verbal structures with more than just a simple finite verb. Zwart's proposal would thus appear to have very little empirical value outside the simple present verbal constructions, and to run the danger of triggering the need to rethink more than it initially explained. Real success for Zwart's analysis of the word order asymmerty is only achieved through its incorporation into a broader analysis of the more complex and intricate verbal workings of the languages it claims to clarify.

\section{Conclusion}

This article has attempted to apply the analysis of verb movement and feature movement proposed in Zwart (1997) on data from Afrikaans. Zwart's proposal has an initial appeal for the analysis of Afrikaans since it accounts for the general asymmetric word order constructions that resemble those in Dutch. However, a number of instances of Afrikaans embedded verb second defy this analysis.

Afrikaans cannot be classified in the same way as other Germanic languages. Espeeially on the contexts in which embedded movement is allowed or not allowed in Mainland Scandinavian-Frisian languages, Afrikaans differs sharply. This casts doubt on the assumption that it is through the lack of a need for $C$ to attract $T$ that embedded clauses remain non-transparent and thus allow for embedded verb movement.

Zwart's analysis does not predict the fact that Afrikaans allows for embedded inversion constructions. Though this problem might be solved by assuming a double $\mathrm{CP}$, this would not explain why the same embedded inversion constructions do not occur in Dutch. 


\section{Bibliography}

Adhikiri, M. (ed.). 1996. Straatpraatjies. Language, politics and popular culture in Cape Town, 1909-1922. Pretoria: Van Schaik Publishers.

Chomsky, N. 1981. Lectures on Government and Binding. Dordrecht: Foris.

Chomsky, N. 1993. A minimalist program for linguistic theory. In Hale, K. and Keyser, S.J. (eds). 1993:1-52.

Chomsky N. 1995. The minimalist program. Cambridge: MIT Press.

Den Besten, H. 1977. On the interaction of root transformations and lexical deletive verbs. In Den Besten, H. 1989.

Den Besten, H. 1978. Cases of possible syntactic interference in the development of Afrikaans. Amsterdam creole studies 11: 5-56.

Den Besten, H. 1981. Marking Wh-movement in Afrikaans. In Muysken, P. (ed.). 1981. Generative studies on creole languages: 141-180. (Studies in generative grammar 6) Dordrecht: Foris.

Den Besten, H. 1986. Double negation and the genesis of Afrikaans. In Muysken P. and Smith, N. (eds). Substrata vs. universals in creole languages: 185-230. Dordrecht: Foris.

Den Besten, H. 1989. Studies in West Germanic syntax. Dissertation, University of Tilburg.

Donaldson, B.C. 1993. A grammar of Afrikaans. Berlin: Mouton de Gruyter.

Feinauer, A.E. 1989. Plasing in Afrikaanse afhanklike sinne. South African Journal of Linguistics: 7(1).

Haegeman, L. 1995. The syntax of negation. (Cambridge studies in linguistics 75) Cambridge: Cambridge University Press.

Haegeman, L. 1996. Finite V-movement in embedded clauses in West Flemish. South African Journal of linguistics 29: 69-104.

Hale, K. and Keyser, S.J. (eds). 1993. The view from building 20. Essays in linguistics in honor of Sylvain Bromberger. Cambridge: MIT Press.

Halle, M. and Marantz, A. 1993. Distributed morphology and the pieces of inflection. In Hale, K. and Keyser, S.J., (eds) 1993: 111-176.

Hellan, L. 1991. A two-level X-bar system. Lingua 84: 239-257.

Hockstra, E. 1991. Licensing conditions on phrase structure. (Groningen dissertations in linguistics 2.) Dissertation, University of Groningen.

Hoekstra, E. 1993. Some implications of number agreement on COMP. In Drijkoningen F. and Henneveld, K. (eds). Linguistics in the Netherlands 1993: 61-68. Amsterdam: John Benjamins. 
Hoekstra, E. and Zwart, C.J.W. 1994. De structuur van de CP: functionele projecties voor topics en vraagwoorden in het Nederlands. Spektator 23: 191-212.

Hooper, J.B. and Thompson, S.A. 1973. On the application of root transformations. Linguistic lnquiry 4: 465-97.

latridou, S. and Kroch, A. 1992. The licensing of CP-recursion and its relevance to the Germanic verb-second phenomenon. Manuscript, University of Pennsylvania.

Kayne, R. 1994. The antisymmetry of syntax. Cambridge: MTT Press.

Koster, J. 1975. Dutch as an SOV language. Linguistics Analysis 1: 111-138.

Koster, J. 1978. Locality principles in syntax. Dordrecht: Foris.

Lubbe, H.J. 1984. Woorvolgordeverandering in die diachroniese ontwikkeling van tale met besondere verwysing na Afrikaans. Publikasiereeks C, no. 8. Universiteit van die Oranje-Vrystaat.

Oosthuizen, J. 1994. 'n Verdere komplement vir COMP. In Van der Merwe, C., Waher, H., Hambidge, J. (eds). 1994. Rondom Roy: studies opgedra aan Roy H. Pheiffer. Departement Afrikaans en Nederlands, University of Cape Town.

Oosthuizen, J. 1996. Minimalisme en woordordevariasie in Afrikaanse vraagsinne. SPIL PLUS 29: 71-98. Department of General Linguistics, University of Stellenbosch.

Pollock, J-Y. 1989. Verb movement, universal grammar and the structure of IP. Linguistic Inquiry 20(3): 365-424.

Ponelis, F.A. 1993. The development of Afrikaans. Duisburger Arbeiten zur Sprach- und Kulturwissenschaft. Frankfurt am Main: Peter Lang Verlag.

Raidt, E.H. 1983. Einführung in Geschichte und Struktur des Afrikaans. Darmstadt: Wissenschaftliche Buchgesellschaft.

Robbers, K. 1997. Non-finite verbal complements in Afrikaans. Unpublished PhD dissertation, University of Leiden.

Stowell, T.A. 1981. Origins of phrase structure. Dissertation, MIT.

Travis, L. 1984. Parameters and effects of word order variation. Dissertation, MIT.

Vikner, S. 1995. Verb movement and expletive subjects in the Germanic languages. Oxford: Oxford University Press.

Weerman, F. 1989. The V2 conspiracy. A synchronic and a diachronic analysis of verbal positions in Germanic languages. Dordrecht: Foris.

Zwart, C.J.W. 1993. Dutch syntax. A minimalist approach. Dissertation, University of Groningen.

Zwart, C.J.W. 1995. A note on verb clusters in the Stellingwerf dialect. In Den Dikken, M. and Hengeveld, K. (eds). Linguistics in the Netherlands: 215-226. Amsterdam: John Benjamins. 
Zwart, C.J.W. 1997. Morphosyntax of verb movement. A minimalist approach to the syntax of Dutch. (Studies in natural language and linguistic theory.) Dordrecht: Kluwer Academic Publishers.

Stellenbosch Papers in Linguistics, Vol. 31, 1998, 95-124 doi: $10.5774 / 31-0-58$ 